\title{
Parody and Appropriation of the Past in the Grandes Chroniques Gargantuines and in Rabelais's Pantagruel (1532)
}

\author{
PaulJ. Smith
}

In 1532 François Rabelais published his first literary work, Pantagruel, which made him immediately known as a satirist. This book (full title: Pantagruel. Les horribles et espoventables faictz et prouesses du tresrenomme Pantagruel Roy des Dipsodes, filz du grant geant Gargantua, Composez nouvellement par maistre Alcofrybas Nasier (Lyon, Claude Nourry: n.d. [1532])) recounts the miraculous life of Pantagruel, the first gentle giant in history. The story is structured according to the topoi of the classical epideictic biography. ${ }^{1}$ In the opening part (genus), the ancestors (maiores) of the giant (chapter 1) are mentioned; in the following part (chapter 2), the story of the miraculous birth of the giant is told (genesis); next, his youth and education are narrated (educatio) (chapters $3^{-24}$ ); the rest of the story (chapters 24/25-33) addresses the exploits of Pantagruel - this part coincides with the facta or res gestae in wartime and in time of peace. ${ }^{2}$

In the genus and educatio parts, Rabelais gives Pantagruel a place in history - even in world history. Rabelais's comic and parodic tone is evident from the opening chapter, entitled "De l'origine et antiquité du grand Pantagruel". Rabelais bestows his giant with a literally antediluvian genealogy, which can be traced back to times long before the Flood. In doing so, Rabelais satirizes by exaggeration the genealogic pretensions of princes and noblemen all over Europe. Chapter 5 narrates how Pantagruel as a student makes an educational journey, visiting France's most important universities. During his "tour de France" the giant leaves his mark on local history. Thus, some reputed lieux de mémoire - the Pierre levée at Poitiers, the Pont du Gard near Arles, and the

1 See Smith P.J., Dispositio. Problematic Ordering in French Renaissance Literature (Leiden Boston: 2007) 25-42.

2 All quotations of the French text refer to Rabelais François, OEuvres complètes, ed. M. Huchon (Paris: 1994). However, Huchon's edition is based on the 1542 edition of Pantagruel, which in many respects (for instance, the number of chapters) is not identical to the 1532 edition. As for the translations, those of the Grandes Chroniques Gargantuines are mine, wheras those of Gargantua and Pantagruel are taken from the translation by M.A. Screech (London: 2006).

(C) PAUL J. SMITH, 2019 | DOI:10.1163/9789004378216_009

This is an open access chapter distributed under the terms of the prevailing CC-BY-NC-ND License 
Amphitheatre of Nîmes - appear to have been created by young Pantagruel. In the same chapter Pantagruel shows how he is fascinated by the history of his own family: the lecture of the chronicles of his ancestors ('les belles chroniques de ses ancestres') makes him visit the tombstone of one of these ancestors, Geoffrey Long-Tooth, one of the sons of the fairy Melusine, from whom the French noble house of Lusignan claimed to be descended.

In this article, I will try to interpret the above-mentioned passages: What is parodied by Rabelais, and how, and what is the place of this parody in the rest of his work? To this end, it is necessary to address preliminarily an anonymous work entitled Les Grandes Chroniques Gargantuines, which was not only the model for Rabelais's Pantagruel, but also its logical predecessor, because the story is about the giant Gargantua, Pantagruel's father. In this work, too, national and local historiography is an important topic.

There is nothing grand about the Grandes Chroniques Gargantuines except its title and its protagonists, who are giants. Indeed, the Grandes Chroniques is a little, anonymous chapbook, with no literary pretentions, published around 1530; the first known version dates from $1532 .{ }^{3}$ This little book is a parody of the Arthurian novels - i.e. the novels on King Arthur and the Round Table, which in their prose versions were widely read in 16th-century France. Its basic story deals with the miraculous birth of the giants Grandgousier and Galemelle, the parents of Gargantua, who were created from the bones of a whale through witchcraft performed by the well-known magician Merlin. We read a comical erotic description of Gargantua's conception, followed by his birth. It is not clear where and in what country Gargantua was born. The only geographical information given is that the giant family was living on top of a mountain. Merlin gave orders to Grandgousier and Galemelle: once Gargantua reached the age of seven years, they had to come to England in order to help King Arthur against his enemies. Therefore, seven years after Gargantua's birth, the two giants and their son depart for England, but the first stop on their trip was Rome. This is an important detail because it indicates that Gargantua's birth

3 Several versions of this work are known, which are often very different from one another. Rabelais himself probably was co-editor of one of these versions, entitled Le Vroy Gargantua (1532). Another version, Les Chroniques admirables du puissant Roy Gargantua (s.l.n.d.), is clearly influenced by Rabelais's early works. Some of these versions are included in Huchon's edition of Rabelais's CEuvres complètes, some others are edited in Les Chroniques Gargantuines, ed. C. Lauvergnat-Gagnière - G. Demerson (Paris: 1988). 
and early life took place somewhere in Italy, south or east of Rome - I will come back to this. Following Merlin's orders, both parents bear an enormous stone on their head, in order to show King Arthur their strength. Just before crossing the Channel, they put their stones down in the sea near the shoreline, with the intention of coming back for them; however, they died suddenly of fever. Let us take a closer look at this deposition of the stones:

[Grandgousier's] rochier à present est appellé le mont Saint-Michel. Et mist ledit grant Gosier la poincte contre mont: et le puis prouver par plusieurs micheletz. Et est ledict rochier tresbien gardé de present au noble roy de France comme vrayes relicques precieuses.

Grandgousier's rock is nowadays called Mont Saint-Michel. And Grandgousier put down the rock with its point upward. And I can prove this by [the testimony] of several Saint-Michel pilgrims. And nowadays this rock is well esteemed by the noble king of France as real precious relics are.

This seems to be important information, as it is supported by the narrator's (mock) protestations of veracity, ${ }^{4}$ based on the eyewitness accounts of the 'micheletz'. And it is the only occasion where the king of France is mentioned in the book. Today, Galemelle's stone is called 'Tombelaine', which is a rocky little island in the sea, near Mont Saint-Michel. Merlin buries Gargantua's parents Grandgousier at Mont Saint-Michel, and Galemelle at Tombelaine.

Before proposing an interpretation of this passage, let us first follow the adventures of Gargantua for a moment. On a magic cloud created by Merlin, Gargantua is transported over the sea to the court of King Arthur. Arthur is presented not as a mighty king, but as a weak, hesitant, and even anxious man, who is not receiving much help from his famous knights of the Round Table. The rest of our story can be summarized briefly: Gargantua helps King Arthur, he defeats all of King Arthur's enemies, and he stays with the king for 200 years, at which point he is transported by Merlin to the Castle of Avalon, where he is still living and feasting with King Arthur.

The Grandes Chroniques is not only a literary parody on the Arthurian novels, but also a political satire on Henry viII, with whom the French king had an alliance against Charles v; this alliance, however, was not always smooth and easy. The French reproached the English king for his general lack of activity

4 This is, accordingly, the comical convention of the liar's tale: the more the tale's veracity is emphasized, the more it is a lie. 
in supporting France, and especially, around 1530, for his dismissal of Cardinal Wolsey, who was befriended by the French diplomat Jean Du Bellay. King Henry surrounded himself with young and ambitious counsellors, among whom was Thomas Cromwell, the future 'hammer of the monks'. It is no coincidence that in the Grandes Chroniques, Merlin summons King Arthur to ask him to be prudent in listening to his bad advisors. The political message of the Grandes Chroniques is that the only real help for King Henry comes from France, personified in the French giant Gargantua. ${ }^{5}$

Another French reproach of the English monarchy was the English king's claim to the French throne - it was only in 1800 that the English King George III dropped this claim and removed the French fleurs-de-lis from the English coat of arms. Henry vin's aspirations came to the fore by his conviction that he descended from King Arthur - this conviction was based upon the immensely popular 12th-century work Historia Regum Britanniae (History of the Kings of Britain) by Geoffrey of Monmouth. This Historia was well known in France: royal propaganda used it in order to set up the Valois' own genealogy, and much of Geoffrey's information passed into the works of French chroniqueurs, including Les grandes croniques de Bretaigne (1514), written by Alain Bouchard. ${ }^{6}$

Let us return to Mont Saint-Michel. Geoffrey of Monmouth narrates how King Arthur defeated a giant at 'the top of that which is now called Michael's Mount. 7 This giant had captured a damsel called Helena. The poor maiden died of fear and was buried in the mountain, 'which, taking the damsel's name, is called Helena's Tomb to this day'. This was, according to the fictitious etymology of Geoffrey, the isle of Tombelaine, which should be read as 'tombe Hélène' - in the words of Bouchard: 'Et pour raison de ce quelle avoit nom Helaine et que elle y fut ensevelie, et aussi que elle y avoit sa tumbe, celluy mont fut dehors appelle Tumbelaine. ${ }^{9}$ As we have seen, the Grandes Chroniques gives another, absurd explanation of the origin of Tombelaine, probably with the intention of parodying Geoffrey's etymology: the fair Helena being replaced with the giantess Galemelle. And concerning Mont Saint-Michel, the Grandes

5 On the political situation at the time of the Grandes Chroniques, see a.o. Huchon M., Rabelais (Paris: 2011) 136-143.

6 Bouchart Alain, Les grandes croniques de Bretaigne, composées en l'an 1514, ed. H. Le Meignen (Rennes: 1886).

7 Geoffrey of Monmouth, Historia Regum Britanniae x, 3: 'in cacumen montis, qui nunc Michaelis dicitur', trans. as The British History by A. Thompson, revised ed. J.A. Giles (London: 1842) 205 .

8 Geoffrey of Monmouth, Historia, x, 3: 'Qui nomen ex tumulo puellae nactus, Tumba Helenae, usque in hodiernum diem, vocatur': trans. ibidem 208.

9 Bouchard, Les grandes croniques, fol. $5^{2 r}$. 
Chroniques comes up with some other possible allusions to Geoffrey's Historia and/or to Bouchard's Croniques. Let us first observe the resemblance between the two texts in the naming of 'Mont Saint-Michel'. Geoffrey wrote, 'which is now called Michael's Mount'; this is echoed by Bouchard, who writes, 'qui a present est appellee le mont Sainct Michel'; ${ }^{10}$ and, the Grandes Chroniques has: 'rochier à present est appellé le mont Saint-Michel'. Whereas neither Geoffrey nor Bouchard pays any further attention to this appellation, the Grandes Chroniques seems to do so, albeit indirectly.

The question is: What has Gargantua to do with the archangel Saint Michael? For this we have to go back to the origins of the cult of Saint Michael in Europe. The original name of the island was Mont Tombe (it is probably that 'tombe' did not originally mean 'tomb', but is derived from an Indo-European word meaning 'elevated'), but in 710 the island was renamed Mont SaintMichel because of the appearance of Saint Michael in a dream of the bishop Saint Aubert of Avranches. In this dream, the Archangel Saint Michael told the bishop to erect a sanctuary. In order to underline his words, the archangel drove his finger into Aubert's head; the hole can still be seen in a skull conserved as a relic at the Saint-Gervais Basilica in Avranches. ${ }^{11}$ This sanctuary was to be constructed in imitation of another sanctuary, erected at the end

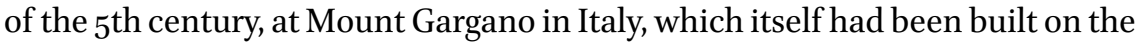
instigation of the Archangel appearing in a dream to Saint Laurence, bishop of Sipontom. The name Gargano is linked to a shepherd, named Garganus, who was miraculously killed by his own arrow on the mountain. On this mountain Saint Michael's sanctuary was built.

Both legends were taken up into the Legenda aurea ${ }^{12}$ and were well spread throughout Europe. They are at the basis of the so-called Via sacra Langobardorum, which connected in a straight line, from northwest to southeast, the four most important monasteries dedicated to the Archangel Michael: Mount St. Michael, a small island in Mount's Bay (Cornwall); the Mont SaintMichel in Normandy; Saint Michael's Abbey in the Susa-Valley near Turin; and Monte Sant'Angelo at Mount Gargano. This straight line can be extended to Jerusalem.

It is into this intertext that the Grandes Chroniques steps in. We have noticed that Gargantua was born not far away from Rome, to the south or east

\footnotetext{
10 Ibidem, fol. $5^{2 \mathrm{v}}$.

11 See https://commons.wikimedia.org/wiki/File:Normandie_Manche_Avranches5_tango7174 .jpg (last consultation 29th October 2017). This skull, by the way, is from a much older, prehistoric date.

12 Jacques de Voragine, La légende dorée, ed. and trans. T. de Wyzewa (Paris: 1910) 545-546, with a different version of the Saint Aubert legend.
} 
of the city, possibly on the same mountain on which the shepherd Garganus was killed. Gargantua and his parents follow the opposite direction of the Via sacra Langobardorum, from Mount Gargano to Mont Saint-Michel. Gargantua is received at King Arthur's court in Camelot, Geoffrey's 'City of Legions', often identified as Caerleon, situated not far away from Mount St. Michael in Wales. And Tintagel, the place where, according to Geoffrey of Monmouth, the conception of King Arthur took place, ${ }^{13}$ is also in the same region - at least as seen from the distanced viewpoint of French readers. Thus, Gargantua's and Arthur's places of conception and birth are geographically linked.

Let us now return to the brief sentence we found in the Grandes Chroniques: 'Et est ledict rochier tresbien gardé de present au noble roy de France comme vrayes relicques precieuses'. Indeed, for the French kings, Mont Saint-Michel was the symbol of their battle against the English aggressors. This is why in 1469 King Louis XI founded the Order of Saint Michael, the centre of which was Mont Saint-Michel. He did so as a reaction against the English Order of the Garter (founded in 1348) and the Burgundian and Imperial Order of the Golden Fleece (founded in 1430). And in 1532, the period in which the Grandes Chroniques was published, King Francis I and his court took Mont Saint-Michel as their starting point for the "tour de France" that they made in order to show the greatness of the French kingdom.

The Mont Saint-Michel episode shows us what has been called a mythologie française, ${ }^{14}$ which implies a strategy of French nationalistic, regional, or local appropriation or reinterpretation of the past: a new signification is given to old, prehistoric, antique, or medieval monuments, or even to phenomena belonging to the natural world. Thus, besides Mont Saint-Michel and Tombelaine, the Grandes Chroniques gives us some other so-called aetiological myths: it explains us, tongue in cheek, why there are no forests in Beauce in Champagne (because Gargantua's mare swept all of the trees away with her tail), why there are no wolves in England (they were all chased and killed by Gargantua), where the Rhône River comes from (from the hot piss of Gargantua), ${ }^{15}$ why the Normans have to drink cider instead of wine (as a punishment, Gargantua had destroyed all of their vineyards) ${ }_{1}^{16}$ and so forth and so on. These comic strategies of popular semantic remotivation would be adopted and developed by François Rabelais.

\footnotetext{
13 Geoffrey of Monmouth, The British History 170.

14 See, for instance, Dontenville H., Mythologie française (Paris: 1973).

15 CEuvres 206. The different versions of the Grandes Chroniques mention several other aetiological explanations of phenomena in which Gargantua is involved.

16 Rabelais, Les Chroniques Gargantuines 275.
} 


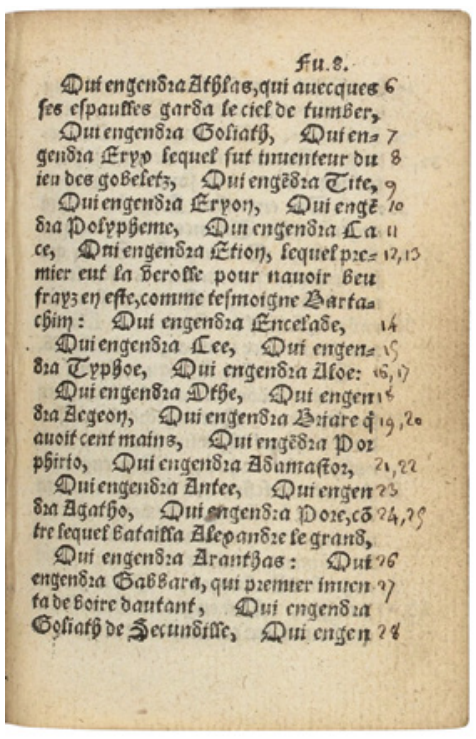

FIGURE 7.1

François Rabelais, Pantagruel, roy des Dipsodes, restitué à son naturel, avec des faictz et prouesses espoventables, composez par feu M. Alcofribas, abstracteur de quinte essence (Lyon, F. Juste: 1542), fol. 8r. Bibliothèque nationale de France RES-Y2-2135 IMAGE @ BIBLIOTHÈQUE NATIONALE DE FRANCE

Rabelais's first novel, Pantagruel (1532), is a logical sequel to the Grandes Chroniques because Pantagruel is the son of Gargantua. But the first chapter on Pantagruel's genealogy also marks a rupture with the Grandes Chroniques. Pantagruel's genealogy does not begin with Grandgousier, created by Merlin's witchcraft, but literally goes back to the antediluvian times before Noah, to the time of Cain and Abel. In the first editions this genealogy has the form of a simple, horizontal enumeration in the form of a typographical block, but from the 1542 editions on, this genealogy begins to take, hesitatingly, the form of a vertical list [Fig. 7.1..$^{17}$

The intertext of this chapter is dazzling. It includes the biblical enumerations of the descendants from Adam and Eve to Christ, all summed up in the same repetitive style of the Bible, 'A begat B' - 'Abraham begat Isaac; and Isaac begat Jacob; and Jacob begat Judas and his brethren' (Matthew 1:2). In a seminal study on this chapter, Edwin Duval ${ }^{18}$ has counted the total of the generations from Adam to Christ, putting together the information from Genesis 5, Genesis 10, Genesis 11, and Matthew 1. Duval arrived at a total of 62 generations between Adam and Christ. Then, Duval counted Pantagruel's ancestors: he

\footnotetext{
17 For this development from enumeration to list, see Cappellen R. - Smith P.J., "Entre l'auteur et l'éditeur. La forme-liste chez Rabelais", L’Année rabelaisienne 1 (2017) 121-144.

18 Duval E.M., The Design of Rabelais's Pantagruel (New Haven - London: 1991) 31.
} 
arrived at 61 . This is in accordance with biblical genealogy because the Bible goes back to Adam, whereas Pantagruel's genealogy stops at Cain and Abel. I found some other evidence in favour of Duval's interpretation: in a copy of the 1542 edition [see Fig. 7.1], an anonymous reader has counted Pantagruel's ancestors, and he also comes to the total of 61 .

It is not only the number that is important, but the organizing principles in this enumeration, namely chronology and the sources used. ${ }^{19}$ This I have visualized in the following quotation of the first part of the genealogy. This part consists of 3 biblical names and 3 names with biblical consonance, all of which I put in bold. Of these, the names Chalbroth, Sarabroth, and Faribroth are inventions by Rabelais, coined on the model of the name of the giant hunter Nembroth (Nimrod). The name of Hurtaly is special; I will come back to him. Then there are 25 names (put in italics) taken from the list of giants by Ravisius Textor, and 4 names (bold italics) from other lists. The presence of 'Sisyphus' in this enumeration is bizarre, and it might be a comical correction of Ravisius Textor, because Textor placed Sisyphus into the list of dwarves.

Et le premier fut Chalbroth, qui engendra Sarabroth, qui engendra Faribroth, qui engendra Hurtaly, qui fut beau mangeur de souppes et regna au temps du deluge, qui engendra Nembroth, qui engendra Athlas qui avecques ses espaules guarda le ciel de tumber, qui engendra Goliath, qui engendra Eryx, qui engendra Titius, qui engendra Eryon, qui engendra Polyphemus, qui engendra Cacus, qui engendra Etion, qui engendra Enceladus, qui engendra Ceus, qui engendra Typhoeus, qui engendra Aloeus, qui engendra Othus, qui engendra Aegeon, qui engendra Briareus qui avoit cent mains, qui engendra Porphyrio, qui engendra Adamastor, qui engendra Anteus, qui engendra Agatho, qui engendra Porus contre lequel batailla Alexandre le grand, qui engendra Aranthas, qui engendra Gabbara, qui engendra Goliath de Secundille, qui engendra Offot: lequel eut terriblement beau nez a boire au baril, qui engendra Artachees, qui engendra Oromedon, qui engendra Gemmagog, qui fut inventeur des souliers a poulaine, qui engendra Sisyphus, qui engendra les Titanes: dont nasquit Hercules, qui engendra Enay, ${ }^{20}$

19 For the identification of these sources, I follow the annotations by Mireille Huchon to her edition of Rabelais's CEuvres complètes 1243-1247.

20 Rabelais François, Les horribles et espoventables faictz et prouesses du très renommé Pantagruel, roy des Dipsodes, filz du grand géant Gargantua, composez nouvellement par Maistre Alcofrybas Nasier (Lyons, Claude Nourry: s.d. [1532]) n.p. Consultable at http:// gallica.bnf.fr/ark:/12148/btvib86095855/fi8.item.zoom (last consultation 6 March 2017). I follow here directly the original 1532 version of Pantagruel, because all reliable modern 
The second part of the list has other sources:

qui engendra Fierabras, lequel fut vaincu par Olivier pair de France compaignon de Roland, qui engendra Morguan, qui engendra Fracassus: duquel a escript Merlinus Coccaius: dont nasquit Ferragus, qui engendra Happemousche qui engendra Bolivorax, qui engendra Longys, qui engendra Gayoffe, qui engendra Maschefain, qui engendra Brulefer, qui engendra Engoulevent, qui engendra Galehaut, qui engendra Myrelangault, qui engendra Galaffre, qui engendra Falourdin, qui engendra Roboastre, qui engendra Sortibrant de Conimbres, qui engendra Brushant de Mommiere, qui engendra Bruyer, lequel fut vaincu par Ogier le dannoys pair de France, qui engendra Mabrun, qui engendra Foutasnon, qui engendra Hacquelebac, qui engendra Vitdegrain, qui engendra Grantgousier, qui engendra Gargantua, qui engendra le noble Pantagruel mon maistre.

Of this list, 14 names (put in bold) are taken from medieval chansons de gestes, and some of them are mock epics: the anonymous Fierabras, Luigi Pulci's Morgante maggiore (1492), and Teofilo Folengo's Baldus (1517), Rabelais's favourite models. There are also 12 names (in italics) taken from folklore or invented by Rabelais, who found his inspiration in popular culture, such as the tradition of Carnival. The first few of these 12 names have to do with eating and swallowing: Happemouche ('Fly-snapper'), Bolivorax (literally 'Earth-eater', which is a composition of Greek bolos, earth, and Latin vorax, eater), Engoulevent ('Wind-swallower'), and Machefain ('Straw-chewer') - which means that in all four cases these giants are monstrous ailing figures of Lent, foreshadowing the ominous giant Quaresmeprenant ('Lent-observer') in Rabelais's Fourth Book (1552). The other names, invented by Rabelais, are obscene: Fout-as-non ('your name is "fuck") and Vit-de-grain ('cock of grain').

But there is more: it is also an allusion to current theories on giants and their origin. Rabelais fabricates his own giantology: Chalbroth, the first giant, became a giant from eating 'les grosses Mesles' ('medlars'), which have grown enormously because they were drenched in the blood of Abel. Another seminal question: How did the giants survive the Flood? To answer this, Rabelais

editions are based on later versions, or they have a tendency to modernize the orthography and/or to put the genealogy into a vertical list. For reasons of space I chose not to include Screech's translation of the whole passage here. 
comes up with the story of Hurtaly - a story he found in the writings of Rabbi Eliezar. ${ }^{21}$ Rabelais writes:

I was not there at the time to tell you about it as I would like to, so I will cite the authority of the Massoretes, those interpreters of the Holy Hebrew Scriptures, who say that Hurtaly was never actually inside Noah's Ark - he could never have got in: he was too big - but that he did sit astride it with a leg on either side like little children on their hobbyhorses. [...] In that way Hurtaly saved the aforesaid Ark from foundering, for he propelled it with his legs, turning it with his foot whichever way he would as one does with the rudder of a boat. ${ }^{22}$

And Noah expressed his gratitude by passing food to Hurtaly through the chimney of the Ark.

Rabelais's mockery seems to target the fictitious, pseudo-scholarly genealogies written by Annio of Viterbo (also Giovanni Nanni, 1498), ${ }^{23}$ and especially by Jean Lemaire de Belges, who in his Illustrations de Gaule et singularités de Troie (1511-1513), reworked the forgery by Annio into a new bogus genealogy with a patriotic message: the French kings are descendants of Noah, who was, in the vision of Lemaire, a giant. Both Annio and Lemaire were much read: Annio's book was printed at least 21 times (last edition in 1612), whereas the three books of the Illustrations de Gaule were published frequently: 9 editions of Book I, 7 editions of Book II, 6 editions of Book III, and 11 complete editions between 1524 and $1549 .{ }^{24}$ During the 16th century, Lemaire's book served the French royal house in helping them claim their ancestral superiority.

What Rabelais thinks of these genealogical frauds can be seen from the opening chapter of Gargantua (1553), Rabelais's sequel to Pantagruel; Gargantua deals with Pantagruel's father, and therefore can be considered a rewriting of the Grandes Chroniques. The narrator addresses himself to the reader in a mildly mocking tone:

Would to God that every man could trace his own ancestry as certainly from Noah's Ark down to this our age! [...] And to enable you to

\footnotetext{
21 See Screech M.A., Rabelais (Ithaca, NY: 1979) 45-47.

22 Rabelais, Gargantua and Pantagruel 20-21.

23 Giovanni Nanni, Commentaria Fratris Joannis Annii Viterbiensis super Opera Diversorum Auctorum de Antiquitatibus Loquentium (Rome, Eucharius Silber: 1498).

24 My count is based on the bibliographical information found in Stephens W.E., Giants in Those Days: Folklore, Ancient History, and Nationalism (Lincoln, NE: 1989) 344-346.
} 
understand me who am talking to you now, I think that I'm descended from some rich king or prince of former times, for never have I seen a man with a greater passion than I have for being rich and a king so as to live in great style, never working [...], and enriching my friends and all good and scholarly folk. ${ }^{25}$

Back now to Pantagruel. In the following chapters the appropriation of the past moves from (inter)national to regional, local, and even, as we shall see, personal, i.e. autobiographical. Thus, in chapter 4 it is recounted how the four huge iron chains by which young Pantagruel was bound in his cradle - and which he broke in order to liberate himself - are now found in different places:

You now have one of those chains at La Rochelle, where they draw it up at night between the two great towers in the haven. Another is at Lyons; another is at Angers, whilst the fourth was borne away by devils in order to hold down Lucifer $\left[\ldots . .{ }^{26}\right.$

In chapter 5 we find some other examples of local remotivation. At the start of his "tour de France" Pantagruel comes to the University of Poitiers:

And he came to Poitiers to study, where he profited greatly. Noticing that the students there did have a little free time but never knew how to use it, he felt compassion for them. So one day, from the great ridge named Passelourdin, he took a big boulder, about two dozen yards square and fourteen span thick, and set it comfortably upon four pillars in the midst of a field in order that the said students, when at a loss over what to do, could pass their time scrambling on to the aforesaid stone, there to feast with plenty of flagons, hams and pasties whilst carving their names on it with penknives. It's called the Pierre levée nowadays.

In memory of which nobody is now matriculated in the said University of Poitiers unless he has drunk from the Caballine Fountain of Croustelles, scaled the Passelourdin and clambered on to the Pierre levée. ${ }^{27}$

\footnotetext{
25 Rabelais, Gargantua and Pantagruel 209-210.

26 Ibidem 28 .

27 Ibidem 30-31.
} 


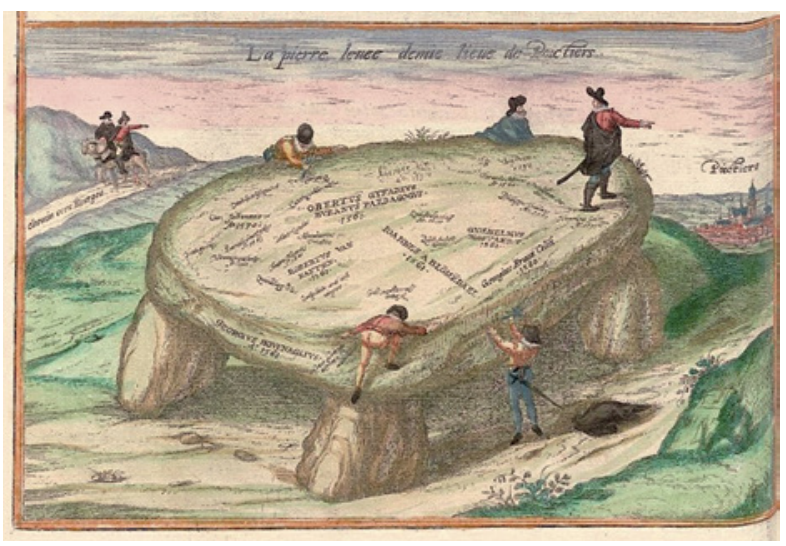

FIGURE 7.2 Joris Hoefnagel, The "Pierre levee", in Georg Braun Frans Hogenberg, Civitates orbis terrarum vol. 5 (Cologne: 1596), detail IMAGE (C) AUTHOR

In this episode we see the same strategy of semantic remotivation as in the case of Mont Saint-Michel in the Grandes Chroniques: a semantically polyvalent monument receives a new mock interpretation. The greater the monument's polyvalence, the better guaranteed the comical effect. This is also the case of the Pierre levée. That is, in Rabelais's time there existed several explanations for this prehistoric construction. This can be seen in the fifth part of the town atlas Civitates orbis terrarum, made by Georg Braun and Frans Hogenberg (ca. 1597), which also gives an intriguing illustration made in 1561 by the Antwerp artist Joris Hoefnagel during his Grand Tour through Europe [Fig. 7.2]:

Much has been written by many about this Stone, of which nothing can be said with certitude how, why and by whom, in times past, this stone has been transported from elsewhere. Many believe however that this stone emerged when the earth that covered it was removed by the elevations of the water, and that it was erected by the local people because of its rarity. On this stone there still exists a hyperbolic poem:

'In weight this stone is superior to the big colossus, and with its enormous mass it reaches to the stars'.28

According to Braun and Hogenberg, these ancient local people who erected the stone were the Pictones, a Celtic tribe from western France, mentioned for 


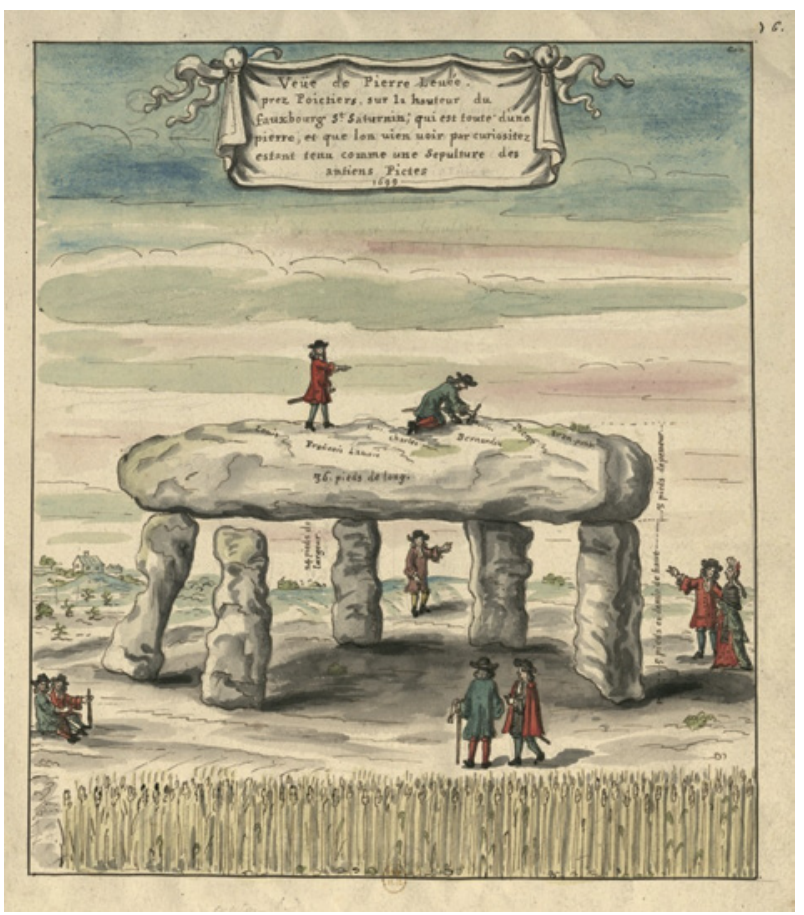

FIgURE 7.3 Louis Boudan, The Pierre levée. Watercolour, in Veüe de Pierre-Levée, prez Poictiers, sur la hauteur du fauxbourg St Saturnin, qui est toute d'une pierre et que l'on vien voir par curiositez estant tenu comme une sépultures des antiens Pictes (1699). Bibliothèque nationale de France, département Estampes et photographie, EST VA-86 (3) IMAGE (C BIBLIOTHÈQUE NATIONALE DE FRANCE

the first time by Julius Caesar, in his De bello Gallico. Pictones is the name from which the name Poitiers has been derived.

We can read this same information in several documents, including a watercolour by Louis Boudan from 1699 [Fig. 7.3], which bears the informative inscription: 'Veüe de Pierre-Levée, prez Poictiers, sur la hauteur du fauxbourg St Saturnin, qui est toute d'une pierre et que l'on vien voir par curiositez estant tenu comme une sépulture des antiens Pictes' (Image of the Pierre levée, near Poitiers, at the height of Faubourg St. Saturnin, which is wholly of stone and which people visit by curiosity, because it is said to be a tomb of the ancient Picts).

There are two other semantic layers attached to the stone, of which Rabelais probably was aware. These we find in the scholarly 18 th-century Rabelais edition by Jacob Le Duchat (1711). In one of his commentaries, we read: 
Cette pierre [...] fut posée en cet endroit sur cinq autres pierres l'an 1478 pour Monument de la Foire qui se tient en Octobre dans le Vieux-Marché de Poitiers. Mais, quoique les Historiens même du Poitou rapportent la chose de cette sorte, les bonnes gens du païs aiment mieux croire que l'entassement de ces Rochers, les uns sur les autres, est un des Miracles de Sainte Radegonde, laquelle, disent-ils, plaça de cette sorte dans ce lieu ces six grosses pierres, dont elle porta, à une seule fois, les cinq moindres dans son tablier, et la plus lourde sur sa tête.

This stone [...] was laid in this place on five other stones in the year 1478 as a Monument of the Fair, which is held in October, at the Old Market of Poitiers. But although even the historians of Poitou report this thing in such a way, the good people of the country prefer to believe that the piling of these rocks, one on the other, is one of the Miracles of Saint Radegund, who, as they say, placed in this place these six large stones, which she carried, all at once, the lighter five in her apron, and the heaviest one on her head. ${ }^{29}$

Reading this passage, one is inclined to think that this Saint Radegund inspired the figure of Galemelle for the anonymous author of the Grandes Chroniques.

As usual, Le Duchat gives his sources. In this case the source is Jean Bouchet, the author of Les Annales d'Aquitaine (first edition 1524) - which brings us very close to Rabelais, because Jean Bouchet is one of Rabelais's friends, and Rabelais refers to him regularly. Therefore, Rabelais must have known about the three aetiological explanations of the Pierre levée (the sepulchre monument of the Pictones, the miracle by Saint Radegund, and the monument on the occasion of the market at Poitiers) - explanations swept away by Pantagruel.

The question is whether the narrator's remark 'In memory of which nobody is now matriculated in the said University of Poitiers unless he has [...] clambered on to the Pierre levee', is also an aetiological re-motivation. Probably not. There are no written or visual testimonies of this custom known before Rabelais, nor do they occur in the time period between Rabelais and the Civitates orbis terrarum. ${ }^{30}$

Here I will allow myself a little digression about Hoefnagel's illustration [see Fig. 7.3]. On this illustration several inscriptions are legible; they are carved

\footnotetext{
29 Rabelais François, CEuvres, ed. Jacob Le Duchat, 6 vols. (Amsterdam, Jean Frédéric Bernard: 1741? [first ed. 1711]), vol. I, 214, n. 7. 
into the stone by his travel companions, among whom we find some people who will be well known later: Guilhelmus Mostaert, Joannes a Blommendael, and Robertus van Haften, as well as Joris Hoefnagel himself, all dated ${ }_{1561 .}$ Another group of inscriptions are dated 1560, and these include some famous names: Gerardus Mercator, Philip Galle, and Frans Hogenberg, the editor of the atlas. Georg Braun, the other editor, also has his inscription (1580; long after Hoefnagel's), and there are some undated inscriptions by the cartographer Abraham Ortelius and the artist Jan Sadeler. No French or other inscriptions are given. Thus, the whole represented scene seems to be highly unrealistic. What Joris Hoefnagel seems to be doing here is putting together the names of his friends, his colleagues, in order to create a kind of community, and linking this to this ancient monument, thus suggesting an eternal friendship, 'an album amicorum in stone.. ${ }^{31}$ Because no mention is known of inscriptions on the Pierre levée between the time of Rabelais and the Civitates orbis terrarum, Hoefnagel and Braun probably took the idea directly from Rabelais, and they were therefore the first to put Rabelais's fantasy into some sort of practice. Due to the international reputation of their atlas, their example was soon followed in the 17th century (see the persons represented in Fig. 7.3), until the 19th century. ${ }^{32}$ This is therefore an unexpected but marvellous instance of the impact of Rabelais's mock aetiological explanation.

\section{4}

\section{Geoffrey Long-Tooth and Melusine}

It is now time to return to Pantagruel and to look at our final example, namely Pantagruel's visit to the tombstone of Geoffrey Long-Tooth, who is related to him by hilariously complex family ties, which are even more complicated in the 1542 edition of the book (the 1542 additions are indicated in bold in the quotation): 33

31 Gerritsen W.P., "Hoefnagel en Ortelius, zwervend door Europa", Omslag. Bulletin van de Universiteitsbibliotheek Leiden en het Scaliger Instituut 2 (2003) 5-8 (7).

32 For the most recent literature on the Pierre levée, see Van der Krogt P., "De Pierre levée bij Poitiers: Een dolmen met graffiti", Caert Thresoor 31, 2 (2012) 35-38.

33 One has attempted to reconstruct the genealogy of the eight family ties mentioned that link Pantagruel to Geoffrey Long-Tooth: grandfather - cousin-in-law - older sister - aunt - son-in-law - uncle - daughter-in-law - mother-in-law. See Gaignebet C., A plus hault sens. L'ésotérisme spirituel et charnel de Rabelais, 2 vols. (Paris: 1986), vol. II 302. 
Afterwards, from reading in the fine chronicles of his forebears, ${ }^{34}$ [Pantagruel] learnt that Geoffrey de Lusignan, called Geoffrey LongTooth - the grandfather of the cousin-in-law of the older sister of the aunt of the son-in-law of the uncle of the daughter-in-law of his mother-in-law - was buried at Maillezais, therefore, as a gentleman should, he rusticated himself for a while to visit the place. [Pantagruel] came to Maillezais, where Pantagruel visited the tomb of Geoffrey LongTooth, whose portrait rather disturbed him when he saw it: he is depicted there as a man in a frenzy, tugging his great malchus half out of its scabbard. Pantagruel asked the reason for it. The canons of the place said they knew no other reason save that Pictoribus atque poetis, and so on, that is, To painters and poets freedom is allowed to portray what they like, how they like. Pantagruel was not satisfied by that answer, and said, 'He is not depicted like that without a reason. I suspect some wrong was done to him as he died, for which he is asking his kinsfolk for vengeance. I will inquire into it more fully and do what is right.' ${ }^{35}$

However, neither Pantagruel nor Rabelais will ever come back to this visit. This is rather typical of Rabelais's suspended way of writing: he promises an interpretation but does not fulfil this promise. Instead he leaves the reader puzzled, challenging him or her to venture an interpretation. What is important for our topic are the two geographical indications that are mentioned: Maillezais and Lusignan.

Maillezais was a Benedictine abbey, serving also as a cathedral, near Poitiers. Because Maillezais was an intellectual centre, young Rabelais, who was in high estimation because of his knowledge of Greek, left the Franciscan order (which was becoming increasingly suspicious of scholarship) and entered Maillezais in 1524 as a monk. Therefore, in a sense, by writing about the Abbey of Maillezais, Rabelais is returning to his own intellectual origins. The humour of this episode will only be grasped by those readers who are well informed about Rabelais's personal biographic data. This is also the case in Gargantua: the war between good King Grandgousier, Gargantua's father, and bad King Picrochole (literally 'bitter bile') is fought in the Chinonais in the Loire Valley, where Rabelais was born, and is probably a comic blow-up of a very local

\footnotetext{
34 This chronicle probably is the chivalric prose novel Les faitz et gestes des nobles conquests de Geoffrey a la Grant Dent (Paris, Jean Trepperel: s.d. [1530], Lyon, Olivier Arnoullet: s.d. [1530]).

Rabelais, Gargantua and Pantagruel 31.
} 
quarrel about fishing rights that occurred in Rabelais's youth between his father, Antoine Rabelais, and his neighbour, a certain Gaucher de Sainte-Marthe. But at the same time the Picrocholian War mirrors the contemporary political conflict which opposed the French king (Grandgousier) against the emperor (Picrochole).

This comic ambivalence between the levels of personal biography and international politics can also be found in the passage on Geoffrey Long-Tooth. Indeed, with the mention of Lusignan, Rabelais refers to the royal house of Lusignan, which ruled in England and France, and which held the kingdoms of Jerusalem, Cyprus, and Armenia. Its origins are in Lusignan, near Poitiers, near Maillezais. The centre of the House of Lusignan was the Castle of Lusignan, destroyed during the Wars of Religion. Therefore, Pantagruel is linked to this royal house, and also to the mythology around this house.

In order to give insight into this mythology, let us turn to André Thevet, Les vrais pourtraits et vies des hommes illustres grecz, latins et payens (1584); this is a textual Hall of Fame, which devotes a chapter and a portrait to Geoffrey LongTooth [Fig. 7.4] ${ }^{36}$ Geoffrey's portrait shows us why he is called 'Long-Tooth': he had a big tooth coming from his lower jaw [Fig. 7.5]. Thevet gives the wellknown explanation for this abnormality: his mother, Melusine, was a monster, half-woman, half-serpent. Geoffrey had nine brothers, eight of which also had a 'mother-mark': one brother had a lion's paw on his cheek, and another, called Horrible by his mother, Melusine, had only one eye on his forehead, like a cyclops - therefore he was killed by his mother at a young age. ${ }^{37}$ Geoffrey had also a 'normal' brother, who entered the Abbey of Maillezais as a monk.

Geoffrey is characterized not only by his protuberant tooth, but also by his ferocity and irascibility. At one moment, in $\mathbf{1 2 2 3}$, his 'normal' brother at the Abbey of Maillezais was badly treated by his fellow monks. On learning this, Geoffrey was taken with anger and burned down the whole abbey. He immediately regretted his action - he went to the pope in Rome to ask for pardon. He was condemned to rebuild the abbey, which he did, and he fought heroically in the crusades in the Holy Land. Thevet tells us how Geoffrey's enemies, frightened by his monstrous appearance, fled like flies. This makes him a real ancestor of Pantagruel, who destroys his enemies in a similar way.

36 Thevet André, Les vrais pourtraits et vies des hommes illustres grecz, latins et payens (Paris, la Vesve Kervert and Guillaume Chaudier: 1584), fols. 239r-240v.

37 For interesting examples and an analysis of contemporary book illustrations of Melusine and her monstrous offspring, see Zeldenrust L., "Serpent or Half-Serpent? Bernhard Richel's Melusine and the Making of a Western European Icon", Neophilologus 100, 1 (2016) $19-41$. 

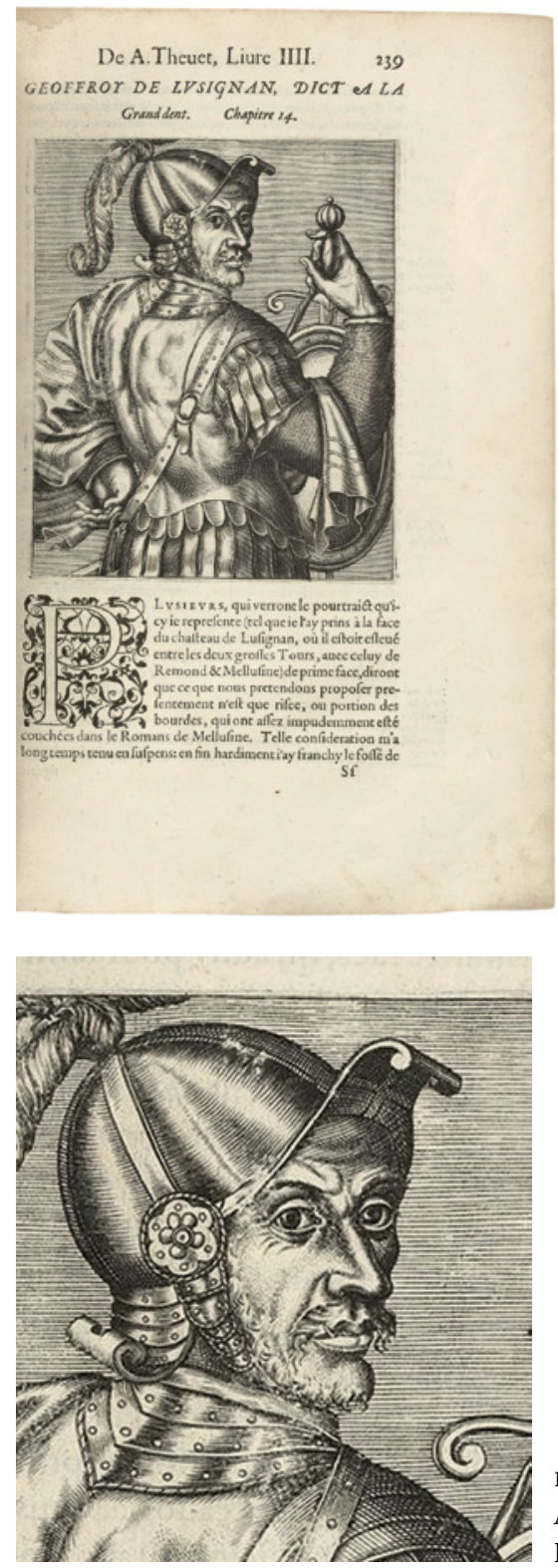

FIGURE 7.4

Anonymous, Geoffrey Long-Tooth. Engraving, taken from: André Thévet, Les vrais pourtraits et vies des hommes illustres grecz, latins et payens, vol. 2 (Paris, widow of I. Kervert and Guillaume Chaudière: 1584), fol. 239r IMAGE (C) BIBLIOTHÈQUE NATIONALE DE FRANCE

FIGURE 7.5

Anonymous, Geoffrey Long-Tooth. Detail from Fig. $7 \cdot 4$

Just like his mother, Melusine, Geoffrey was to become a mythical figure. It is not impossible that Rabelais played a role in this. That is, nothing is known about a portrait of Geoffrey at Maillezais in Rabelais's time - so it is not certain that Geoffrey's portrait, contemplated by Pantagruel, really existed. Maybe it was pure invention by Rabelais, just as we saw with the students' graffiti on the Pierre levée. Be that as it may, in the 19th century a stone head 


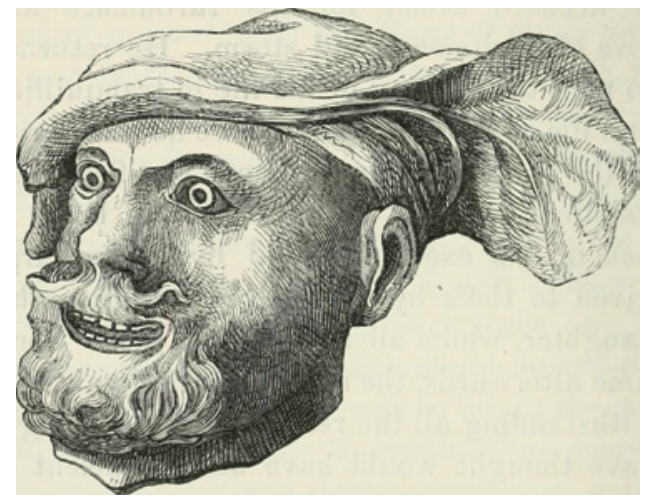

FIGURE 7.6

Stone head found in April 1834 in the cathedral of Maillezais. Print taken from: Thomas Adolphus Trollope, A summer in western France (London: 1841) 114 IMAGE (C) WIKIMEDIA

was discovered in the cathedral of Maillezais [Fig. 7.6]. ${ }^{38}$ According to tradition, this could be the sculpted portrait of Geoffrey Long-Tooth, as Rabelais described it. But, although the represented figure shows two rows of big teeth, he has no protuberant tooth, and, moreover, we are dealing here with a sculpture, not a painted portrait. Therefore, this anonymous figure, who probably was not Geoffrey Long-Tooth, became Geoffrey by a semantic remotivation of the past - a remotivation invented by Rabelais.

\section{$5 \quad$ Epilogue}

During his "tour de France" Pantagruel continues to remotivate the past. Passing through Provence, the giant is 'halting en route to build the Pont du Gard and the Amphitheatre at Nîmes in less than three hours, yet it looks more divine than human.39 But things change after his visit to the University of Orléans. Ending his tour in Paris, the young giant leaves behind his past, both national and local, and steps into the actuality of Paris.

In Pantagruel, Rabelais's appropriation of the past has the objective of distinguishing his first book from the Grandes Chroniques Gargantuines by actualizing the unilateral, anti-English political satire of his anonymous predecessor, and by refining the Chroniques' literary parody. Moreover, he endows the young giant with an ancestral past, which was lacking in the Chroniques, Gargantua and Galemelle being created by Merlin's witchcraft. Through this, Rabelais's appropriation of the past plays an essential role in the genus and education parts of his first book, thus laying the basis of the cycle of his five books on Gargantua and Pantagruel.

38 Trollope T.A, A Summer in Western France (London: 1841), vol. II, 114.

39 Rabelais, Gargantua and Pantagruel 32. 


\section{Bibliography}

Bouchart Alain, Les grandes croniques de Bretaigne, composées en l'an 1514, ed. H. Le Meignen (Rennes: 1886).

Braun Georg - Hogenberg Frans, Civitates orbis terrarum, vol. 5 (Cologne: n.d.).

Cappellen R. - Smith P.J., "Entre l'auteur et l'éditeur. La forme-liste chez Rabelais", L'Année rabelaisienne 1 (2017) 121-144.

Dontenville H., Mythologie française (Paris: 1973).

Duval E.M., The Design of Rabelais's Pantagruel (New Haven - London: 1991).

Gaignebet C., A plus hault sens. L'ésotérisme spirituel et charnel de Rabelais, 2 vols. (Paris: 1986).

Geoffrey of Monmouth, The British History, trans. A. Thompson, revised ed. J.A. Giles (London: 1842).

Gerritsen W.P., "Hoefnagel en Ortelius, zwervend door Europa”, Omslag. Bulletin van de Universiteitsbibliotheek Leiden en het Scaliger Instituut 2 (2003) 5-8.

Huchon M., Rabelais (Paris: 2011).

Jacques de Voragine, La légende dorée, ed. and trans. T. de Wyzewa (Paris: 1910).

Les Chroniques Gargantuines, eds. C. Lauvergnat-Gagnière - D. Demerson (Paris: 1988).

Rabelais François, Les horribles et espoventables faictz et prouesses du très renommé

Pantagruel, roy des Dipsodes, filz du grand géant Gargantua, composez nouvellement par Maistre Alcofrybas Nasier (Lyons, Claude Nourry: s.d. [1532]). Consultable at http://gallica.bnf.fr/ark:/12148/btvib86095855/fi8.item.zoom (last consultation 6 March 2017).

Rabelais François, OEuvres, ed. Jacob Le Duchat, 6 vols. (Amsterdam, Jean Frédéric Bernard: 1751 [first ed. 1711]).

Rabelais François, OEuvres complètes, ed. M. Huchon (Paris: 1994).

Rabelais François, Gargantua and Pantagruel, ed. and trans. M.A. Screech (London: 2006).

Screech M.A., Rabelais (Ithaca, NY: 1979) 45-47.

Smith P.J., Dispositio. Problematic Ordering in French Renaissance Literature (Leiden Boston: 2007).

Stephens W.E., Giants in Those Days: Folklore, Ancient History, and Nationalism (Lincoln, NE: 1989) 344-346.

Thevet André, Les vrais pourtraits et vies des hommes illustres grecz, latins et payens (Paris, the widow Kervert and Guillaume Chaudier: 1584).

Trollope T.A, A Summer in Western France, 2 vols. (London: 1841).

Van der Krogt P., "De Pierre levée bij Poitiers: Een dolmen met graffiti”, Caert Thresoor 31,2 (2012) 35-38.

Zeldenrust L., "Serpent or Half-Serpent? Bernhard Richel's Melusine and the Making of a Western European Icon", Neophilologus 100, 1 (2016) 19-41. 